\title{
Kvalita trofejí lovených druhov kopytníkov na severovýchode Slovenska (Cetartiodactyla)
}

\author{
Jozef ŠTOFÍK
}

Štátna ochrana prírody SR, Správa Národného parku Poloniny, ul. Mieru 193, SK-067 61 Stakčín; jozef.stofik@sopsr.sk

došlo 15. júna 2021

Trophy quality in hunted ungulates in northeastern Slovakia (Cetartiodactyla). Based on the data from trophy hunting statistics (1997-2019), this paper describes changes in the potential economic trophy value evaluation of hunted ungulates (PETV) by comparison of two groups of areas, (1) the hunting grounds with wolf protection (since 2014), and (2) the hunting grounds without wolf protection. In both groups of areas in the long-term aspect (1997-2019), the value of PETV had an increasing trend in the roe deer, wild boar, and red deer. Since 2014, in the areas with wolf protection the average value of PETV was at the level of $249 € /$ year $/ \mathrm{km}^{2}$ (SD $69 € /$ year $/ \mathrm{km}^{2}$ ) and in the areas without wolf protection, it was $185 € /$ year $/ \mathrm{km}^{2}$ (SD $8 € /$ year $/ \mathrm{km}^{2}$ ). Since 2014 , in the areas with wolf protection, the mortality did not affect the PETV trend, but in the red deer a significant fluctuation in PETV values was observed compared to the previous period. Since 2014, in the areas with wolf protection, a qualitative increase in the value of hunted red deer trophies was registered, in almost all C.I.C. categories above 170 points.

Key words. Ungulates, red deer, roe deer, wild boar, hunting, wolf protection.

\section{ÚVOD}

V Slovenskej republike zákon o pol’ovníctve nerieši výslovne právny status, resp. vlastníctvo vol’ne žijúcej zveri (BuBELíNY 2014). Avšak zákon o pol’ovníctve stanovuje, že ulovená, usmrtená, uhynutá zver, alebo jej časti nachádzajúce sa v pol’ovnom revíri, patria užívatel'ovi pol'ovného revíru (ANONYMUs 2009b), ktorý ma nájomnú zmluvu s vlastníkom (ANONYMUS 1992). Užívatel'ovi pol'ovného revíru zákon o pol’ovníctve (ANONYMUs 2009b) stanovuje povinnosti týkajúce sa starostlivosti o zver a zodpovednost' za dodržiavanie právnych predpisov týkajúcich sa pol'ovníctva. V zmysle nájomnej zmluvy patrí vlastníkovi pol’ovných pozemkov primeraná náhrada (ANONYMUS 1992), ktorá sa v súčasnosti vypočítava podl'a sadzobníka na výpočet náhrad za pol'ovné pozemky pre hlavné druhy lovnej zveri (ANONYMUs 2009b) na základe bonity územia (ANONYMUs 2009c).

Najefektívnejšu formu zhodnotenia produkcie pol'ovných pozemkov predstavuje organizovanie pol'ovníckej turistiky a poplatkového lovu (LEHOCKÝ \& KURIC 2007, RIVRUD et al. 2013). Poplatkový lov je popri organizačných poplatkoch (ANONYMUs 2017, 2018a, b, 2019a, b, c) zameraný aj na kvalitatívne zhodnotenie chovu úlovkami. Zákon o pol'ovníctve (ANONYMUS 2009 b) pod odbornou starostlivost'ou o chov definuje aj dosiahnutie kvality trofejí. Kvalita sa zist'uje na chovatel'ských prehliadkach a hodnotí bodmi Mezinárodnej rady pre pol'ovníctvo 
a ochranu zveri (Conseil International de la Chasse et de la Conservation du Gibier, C.I.C.) a v nadväznosti na získané body sa významnejším trofejam pridel’ujú medaily (ANONYMUS 2009c). Medaily udel'ované trofejam slúžia predovšetkým k sút’aženiu medzi pol'ovníkmi, regiónmi, ba aj štátmi (Hell et al. 2009).

Aktivity v súvislosti s poplatkovým lovom úzko súvisia s chovom zveri, pod čím sa rozumie odborná starostlivost' o zver, ochrana zveri a odborný zásah do populácií jednotlivých druhov zveri na dosiahnutie jej optimálneho počtu, vekovej štruktúry, pomeru pohlavia, kvality trofejí a dobrého zdravotného stavu vo vzt'ahu k životnému prostrediu (ANONYMUs 2009b).

V rámci filozofie pol'ovníctva sa stáva aktuálnou témou ekologizácia pol'ovníctva (KROPIL et al. 2015, SMOLKo et al. 2018) so zameraním na prírodo-ochranný a ekologicko-environmentálny aspekt (SLÁDEK 2011). V ekologicky nedotknutých ekosystémoch zohrávajú účinky vrcholových predátorov zhora nadol zásadnú úlohu pri formovaní trofických vzt’ahov a štruktúrovaní ekosystémov, ale v človekom upravenej krajine môžu antropogénne vplyvy výrazne zmenit' ekologickú úlohu predátorov (CIUCCI et al. 2019), pričom vlci silne ovplyvňujú využitie územia jeleňmi (BuBNicKi et al. 2019).

Prípustná úroveň hustoty zveri závisí od ekologického a sociálno-ekonomického kontextu, v ktorom sa obyvatel'stvo nachádza (CARPIO et al. 2020). V roku 2014 bola na Slovensku implementovaná územná ochrana vlka dravého (ANTAL et al. 2016), s čím súvisí zákaz lovu vlka v určených územiach.

Ciel'om predkladaného príspevku je porovnat' potenciál kvalitatívnych zmien jedného z najvýznamnejších aspektov pol’ovníctva, ktorým je trofejové zhodnotenie kopytníkov, v pol'ovných revíroch v nadväznosti na zavedenie územnej ochrany vlka na severovýchode Slovenska.

\section{MATERIÁL A METODIKA}

Záujmové územie (pol'ovné revíry okresov Snina, Humenné a Medzilaborce; výmera $1.844 \mathrm{~km}^{2}$ ) sa nachádza na severovýchode Slovenska. Severná a východná hranica kopíruje štátnu hranicu Slovenska

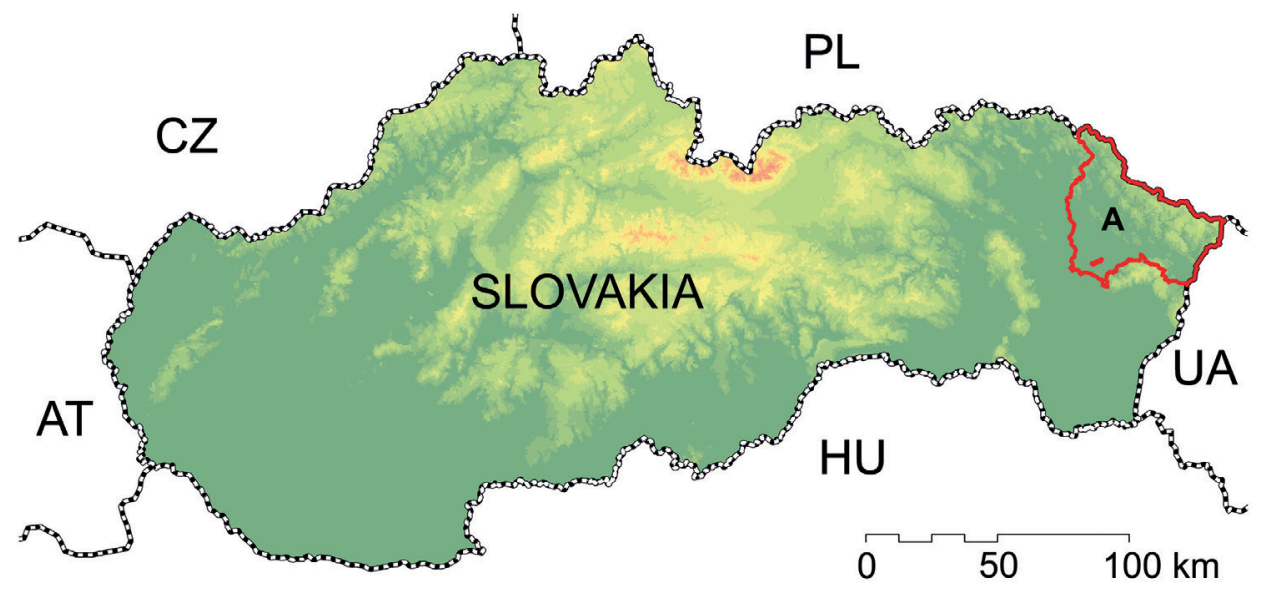

Obr. 1. Mapa hodnoteného územia (A). 
Tab. 1. Úbytok jedincov druhov z trofejovej štatistiky hodnoteného územia (1997-2020). Druhy: DD Dama dama, SS - Sus scrofa, MM - Meles meles, CE - Cervus elaphus, VV - Vulpes vulpes, FS - Felis silvestris, $\mathrm{OM}$ - Ovis musimon, $\mathrm{NP}$-Nyctereutes procyonoides, LL-Lynx lynx, CC-Capreolus capreolus, $\mathrm{CA}-$ Canis aureus, $\mathrm{CL}-$ Canis lupus

\begin{tabular}{lrrrrrrrrrrrr}
\hline druh & DD & SS & MM & CE & VV & FS & OM & NP & LL & CC & CA & CL \\
\hline lov & 98 & 856 & 101 & 4561 & 40 & 4 & 42 & 26 & 3 & 6026 & 0 & 167 \\
úhyn & 0 & 13 & 0 & 424 & 0 & 2 & 2 & 0 & 0 & 391 & 1 & 4 \\
\hline
\end{tabular}

a južná a západná hranica kopíruje administratívnu hranicu pôsobnosti Obvodnej pol’ovníckej komory v Humennom (obr. 1).

V práci boli použité údaje o vybraných druhoch trofejovej zveri (tab. 1) hodnoteného územia z obdobia rokov 1997-2020 (ANONYMus 1998, 1999, 2000, 2001, 2002a, 2003a, 2004, 2005, 2006, 2007, 2008, 2009, 2010, 2011, 2012, 2013, 2014, 2015, 2016, 2017b, 2018c, 2019d, 2020) - trofejová štatistika (d’alej len TŠ) a GIS vrstva pol’ovných revírov hodnoteného územia a územia Slovenskej republiky (CNLC 2002).

Metóda spracovania údajov pozostávala z nasledujúcich krokov: (1) analýza úbytku kopytníkov z TŠ v období 1997-2020 pre jednotlivé pol’ovné revíry (PR); (2) zhodnotenie potenciálnej medailovej významnosti kopytníkov z TŚ (počet a druh medailí v PR pre jednotlivé druhy); (3) zhodnotenie potenciálnej ekonomickej trofejovej významnosti (d’alej len PETV) kopytníkov prepočtom cez C.I.C. hodnoty (ANONYMUs 2019a) poplatku za odstrel na PR (€/rok/PR); (4) prepočet (štandardizácia na km²) PETV v rámci $\mathrm{PR}\left(€ / \mathrm{rok} / \mathrm{km}^{2}\right)$ pre vybrané druhy (jeleň $-\mathrm{PETV}_{\mathrm{CE}}$; diviak - PETV $\mathrm{SS}_{\mathrm{SS}}$ a srnec $\left.-\mathrm{PETV}_{\mathrm{CC}}\right)$ a súhrnne (jeleň+ diviak + srnec + muflón + daniel $=$ PETV $V_{\mathrm{SA}}$ ) v nadväznosti na predchádzajúci krok; (5) porovnanie PETV medzi časovými obdobiami (1997-2013, vs. 2014-2019) a priestorovými zmenami v PR nachádzajúcich sa v oblasti s územnou ochranou vlka (resp. v prekryve s väčšou čast’ou), ktorá bola definovaná v roku $2014\left(\mathrm{n}=21 ; 617 \mathrm{~km}^{2}\right)$ - vlk, a porovnanie s PR nachádzajúcimi sa v oblasti mimo územnej ochrany vlka ( $\left.\mathrm{n}=44 ; 1.227 \mathrm{~km}^{2}\right)$ - mimo (obr. 2); (6) analýza úhynu a porovnanie zmien v PETV hodnoteného časového rámca (5); (7) spracovanie výstupov (body 2-5) v prostredí GIS (na podklade vrstvy pol'ovných revírov CNLC 2002) a porovnanie vyhodnotených údajov v súvislosti s ich lokalizáciou vo vzt’ahu k oblasti s územnou ochranou vlka (obr. 4).

Použité SKRATKY. CC - Capreolus capreolus srnec hôrny; CE - Cervus elaphus jeleň lesný; CHPO chránená pol'ovná oblast'; C.I.C. - Conseil International de la Chasse et de la Conservation du Gibier (Medzinárodná rada pre pol'ovníctvo a ochranu zveri); DD - Dama dama daniel škvrnitý; GIS - Geografic Information System (Geografický informačný systém); n - počet jedincov; NLC - Národné lesnícke centrum; O - ostatné pol’ovné revíry (mimo W); OM - Ovis musimon muflon lesný; PETV - Potenciálne ekonomické zhodnotenie trofejovej významnosti druhu respektíve skupiny; PR - pol’ovný revír; SD Standard Deviation (smerodajná odchýlka); SS - Sus scrofa diviak lesný; TŠ - trofejová štatistika; W - pol'ovné revíry vyhodnocované ako oblast's územnou ochranou vlka; W (2014) - územie zadefinované legislatívne v roku 2014 ako územie s ochranou vlka; \% - relatívne hodnoty porovnávaných atribútov; $€$ - potenciálne ekonomické zhodnotenie vybraných atribútov hodnotenej lokality; $€ /$ rok $/ \mathrm{km}^{2}$ (€/year/ $\mathrm{km}^{2}$ ) - štandardizované potenciálne ekonomické zhodnotenie vybraných atribútov (potenciálna hodnota $\mathrm{v} €$ prepočítaná na 1 rok a $1 \mathrm{~km}^{2}$ ).

\section{VÝSLEDKY}

V hodnotenom území bol v období rokov 1997-2020 do analýz započítaný úbytok 12413 trofejových jedincov kopytníkov (obr. 2). V rámci hodnotených druhov to predstavovalo 4985 (úhyn 9,3\%) jedincov jelenov, 6417 (úhyn 6,5\%) srncov, 869 (úhyn 1,5\%) diviakov, 98 (úhyn $0 \%$ ) danielov a 44 (úhyn 4,8\%) muflonov. 


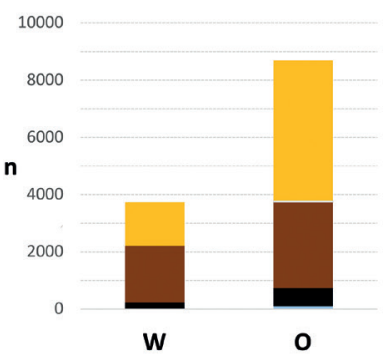

B

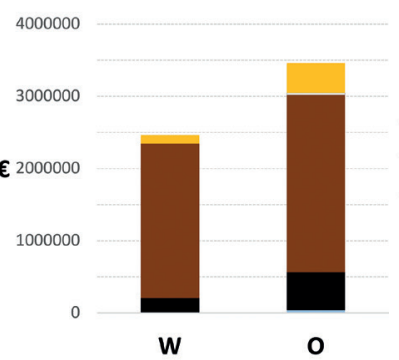

C

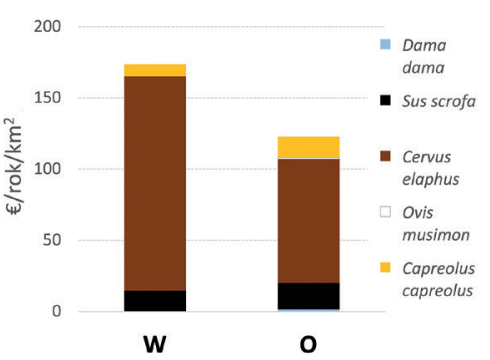

Obr. 2. Úbytok trofejových druhov kopytníkov v hodnotenom území (1997-2020). A - počet ulovených jedincov v porovnávaných oblastiach; B - potenciálna ekonomická trofejová hodnota lovených druhov (PETV) v porovnávaných oblastiach; $\mathrm{C}$ - štandardizovaná potencionálna hodnota lovených druhov v porovnávaných oblastiach. $\mathrm{W}$ - pol’ovné revíry s územnou ochranou vlka; $\mathrm{O}$ - ostatné pol’ovné revíry.

Porovnaním vybraných oblastí bol vyhodnotený rozdiel v trofejovom potenciáli hodnotených oblastí (obr. 2C), ako aj v štruktúre potenciálu lovených druhov (obr. 3). Analýza PETV (1997-2019) naznačuje, že oblast' (obr. 2C), v ktorej bola od roku 2014 ustanovená územná ochrana vlka (obr. 4), je na tom v porovnaní s PETV ostatných PR lepšie.

Na základe výstupov zo zhodnotenia PETV a vzájomným porovnaním PR po roku 2014 (obr. 4) je možné pozorovat' výrazné disproporcie hodnotených PR v jednotlivých oblastiach.

\section{Jeleň lesný (Cervus elaphus)}

Jelen lesný je v hodnotenom území majoritným loveným druhom, ktorý sa najvýraznejšie (obr. 2B, C) podiel'a na PETV jednotlivých PR (obr. 4). Porovnaním štandardizovaných dát medzi obdobím pred a po roku 2014 sa dá pozorovat' výrazný pokles v obidvoch hodnotených oblastiach v prípade trofejí v triedach 100-170 bodov C.I.C. (obr. 5). Na druhej strane je vyhodnotený
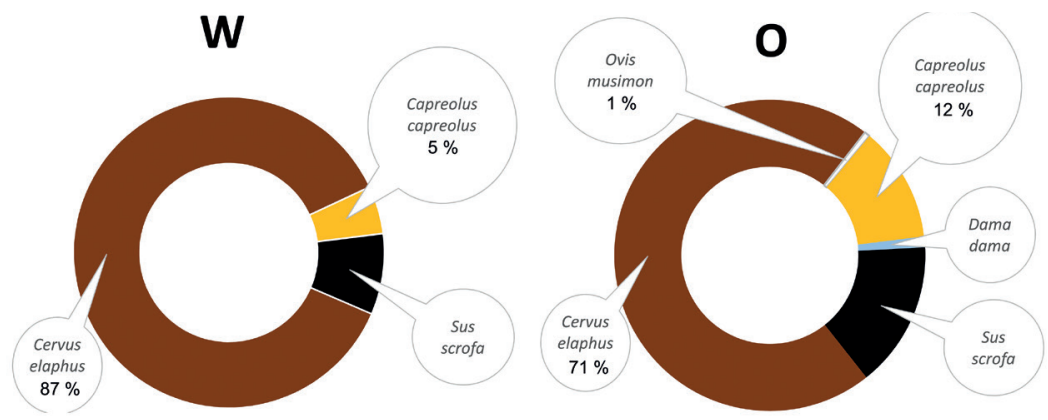

Obr. 3. Relatívne zhodnotenie štandardizovanej $\left(€ / \mathrm{rok} / \mathrm{km}^{2}\right)$ potencionálnej ekonomickej trofejovej hodnoty lovených druhov kopytníkov (PETV) v hodnotených oblastiach (1997-2020). W - pol'ovné revíry s územnou ochranou vlka; $\mathrm{O}$ - ostatné pol'ovné revíry. 
nárast v triede do 100 bodov C.I.C. a výraznejší nárast takmer vo všetkých najhodnotnejších kategóriách C.I.C. nad 170 bodov v PR v oblasti s územnou ochranou vlka.

Zvýšený lov medailových jedincov jeleňa je v súčasnosti (2014-2019) situovaný v severozápadnej a severovýchodnej časti hodnoteného územia, pričom smerom na juhozápad sa medailový potenciál tohto druhu znižuje (obr. 6). Vzhl'adom na najvýraznejší podiel jeleňov (obr. 3), ako aj hodnôt PETV $_{\mathrm{CE}}$ (obr. 5) oproti ostatným druhom (obr. 7 a 9) je zrejmý vplyv PETV CE $_{\text {na }}$ PETV jednotlivých PR (obr. 4).

V období 2014-2019 bolo zo všetkých hodnotených ulovených jedincov ( $n=1.950) 12 \%$ medailových jedincov (z toho zlatých $0,51 \%$ ). V rámci $P R$ najlepšie zhodnocujú chov jeleňov

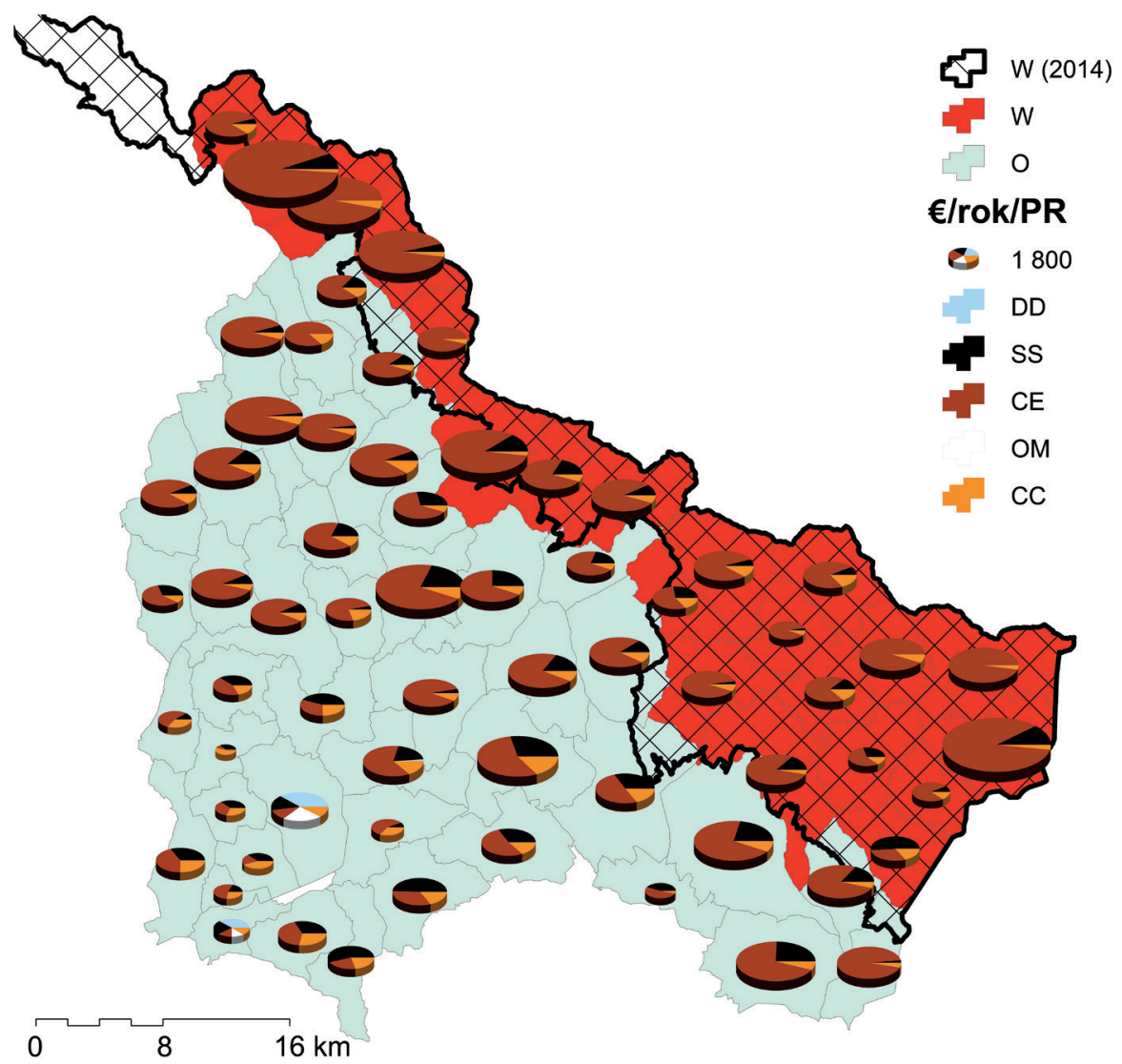

Obr. 4. Disperzia štandardizovaných hodnôt (€/rok/pol'ovný revír) potencionálnej ekonomickej trofejovej významnosti (PETV) vybraných lovených druhov kopytníkov v jednotlivých pol'ovných revíroch (2014-2020); dáta spracované bez úhynu. W - pol'ovné revíry s ochranou vlka; O - ostatné pol'ovné revíry; W (2014) - územie s ochranou vlka definovanou legislatívne; 1.500 - mierka symbolu $1.500 € /$ rok/pre pol’ovný revír; DD - daniel škvrnitý Dama dama; SS - diviak lesný Sus scrofa; CE - jeleň lesný Cervus elaphus; OM - muflon lesný Ovis musimon; CC - srnec hôrny Capreolus capreolus. 
lovom v PR Jeseník (n=36, vlk), kde medailové jedince tvorili $47 \%$ (zlaté $3 \%$ ). Nasleduje PR Kosmatec ( $\mathrm{n}=23$, mimo) kde medailové jedince tvorili $39 \%$ (zlaté $0 \%$ ) a tretí v poradí je PR Hudakov ( $\mathrm{n}=28$, vlk), kde medailové jedince tvorili $35 \%$ (zlaté $5 \%$ ) zo všetkých ulovených trofejových jedincov (2014-2019). Vzájomný pomer medailových trofejí (zlatá : strieborná : bronzová) bol 1:6:17 ( $\mathrm{n}=239)$.

\section{Diviak lesný (Sus scrofa)}

Diviak lesný je tretím najvýznamnejším loveným druhom (obr. 2A), ktorý sa výraznejším podielom podiel'a na PETV v rámci jednotlivých $\mathrm{PR}$, ako aj hodnoteného územia (obr. 3,4$)$.

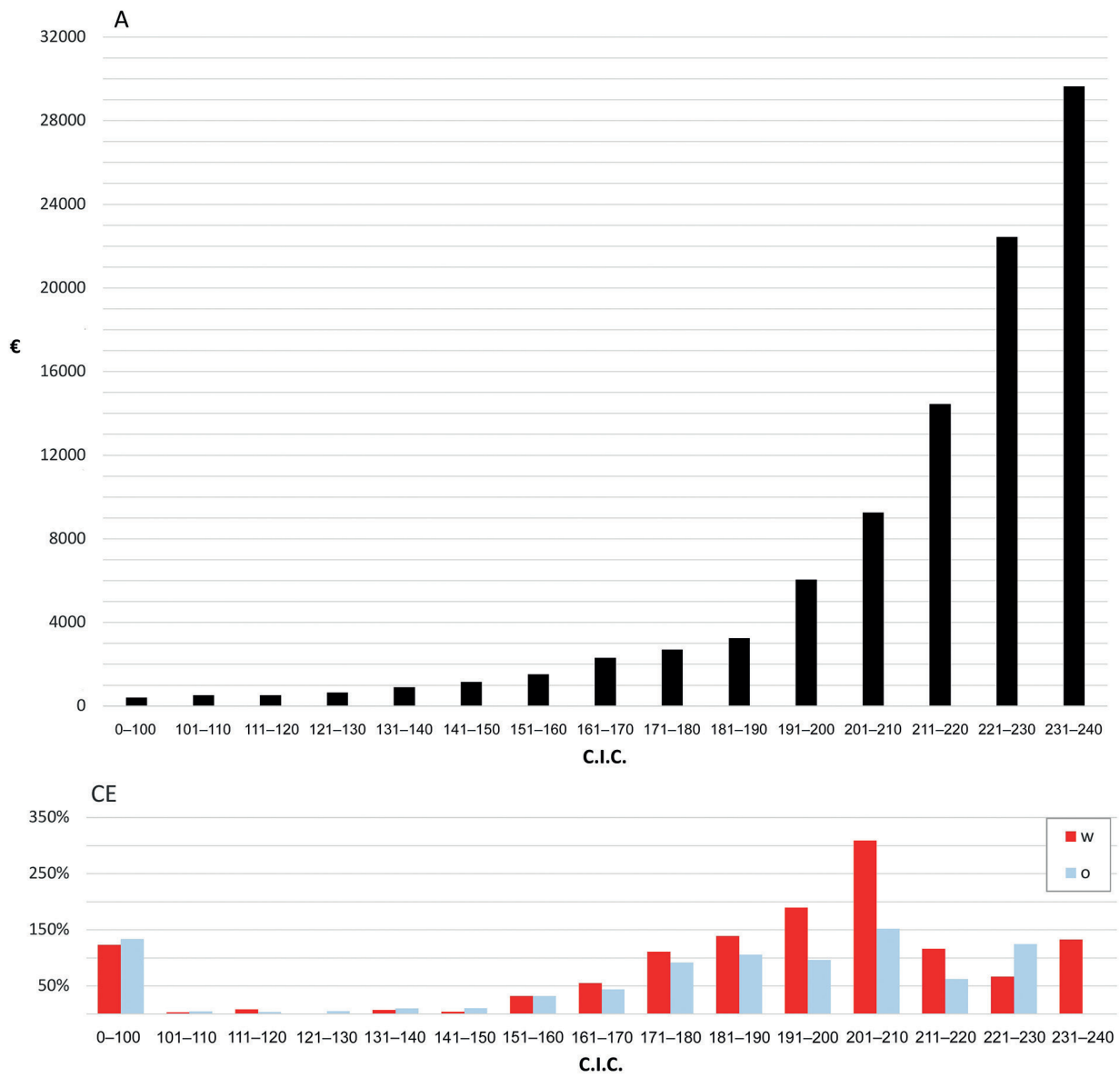

Obr. 5. Závislost' ekonomického zhodnotenia ( $€$ ) a kategórií C.I.C. jeleňa lesného (ANONYmus 2019a). CE - porovnanie zmien medzi obdobiami 2014-2019 vs. 1997-2013 trofejového rozvrstvenia ulovených jeleňov - CE; hodnotené údaje bez úhynu. $\mathrm{W}$ - pol'ovné revíry s územnou ochranou vlka; O - ostatné pol'ovné revíry. 


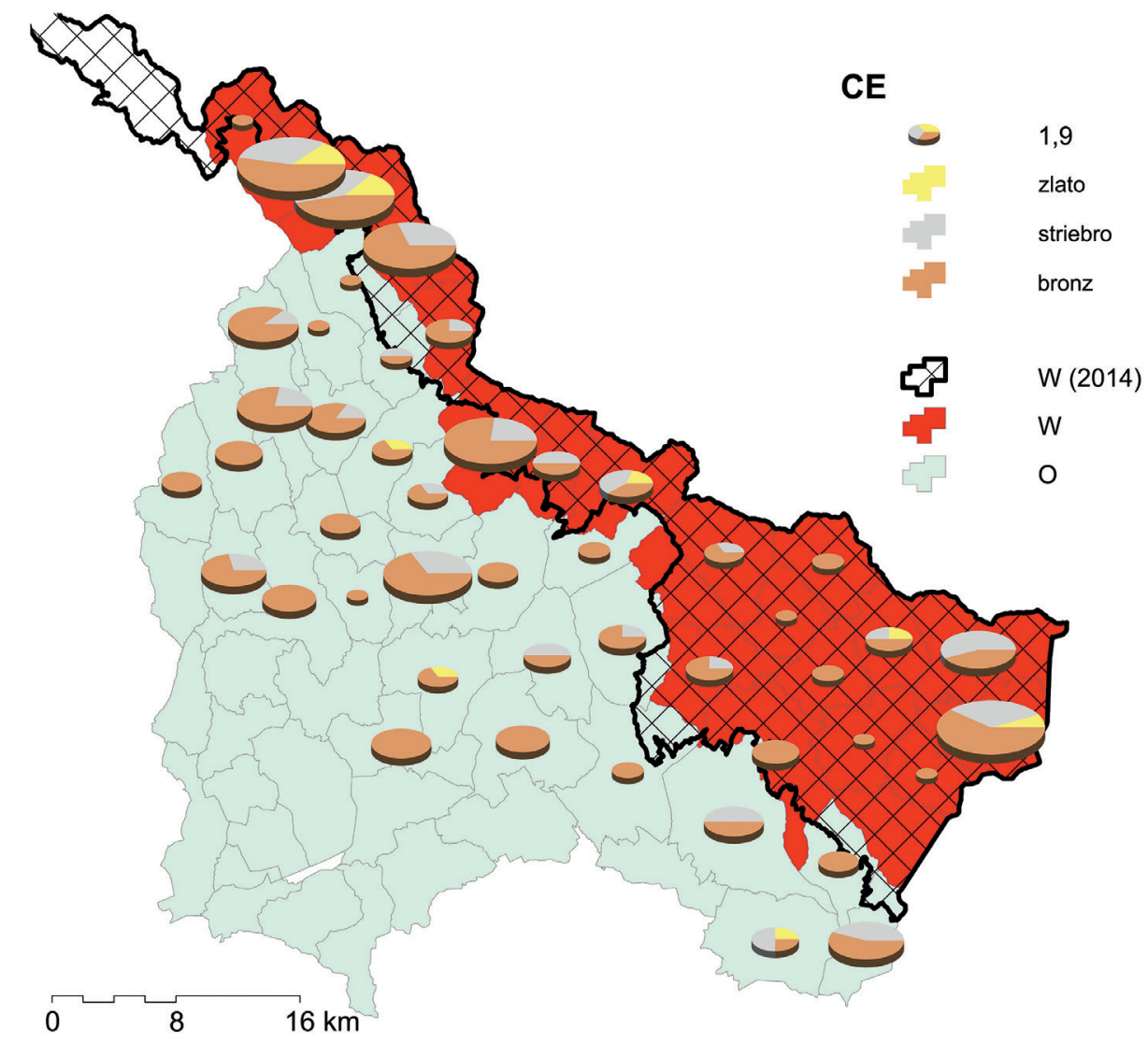

Obr. 6. Disperzia ulovených medailových jedincov jeleňa lesného (CE) v hodnotených oblastiach (2014-2019); dáta spracované bez úhynu. 1,9 - mierka symbolu $=1,9$ medaily na pol’ovný revír; W (2014) - oblast' s prísnou ochranou vlka od roku 2014; W - pol'ovné revíry s územnou ochranou vlka; $\mathrm{O}$ - ostatné pol'ovné revíry.

Porovnaním štandardizovaných dát medzi obdobím pred a po roku 2014 je možné pozorovat' výrazný pokles u trofejí v triedach 100-110 bodov C.I.C. Na druhej strane sa zistil výraznejší nárast v oboch oblastiach $\mathrm{v}$ triede do 100 bodov C.I.C. a výraznejší nárast takmer vo všetkých kategóriách C.I.C. nad 110 bodov, a to prevažne v oblasti mimo územnej ochrany vlka (obr. 7).

Relatívne vyšší podiel medailových jedincov (2014-2019) je situovaný v južne situovaných PR okresu Snina, severne situovaných PR okresu Humenné a západne situovaných PR okresu Medzilaborce (obr. 8).

Medailových jedincov zo všetkých hodnotených jedincov (n=405) bolo v období 2014-2019 $48 \%$ (z toho zlatých 9,38 \%). V prípade 11 PR tvorili medailové jedince $100 \% \mathrm{z}$ lovu, a to konkrétne: PR Bilanka ( $\mathrm{n}=2$, zlaté $100 \%$, mimo), PR Brezník ( $\mathrm{n}=6$, zlaté $17 \%$, mimo), PR Jesenovec ( $\mathrm{n}=2$, zlaté $50 \%$, mimo), PR Jazvec ( $\mathrm{n}=1$, zlaté $100 \%$, mimo), PR Kolodník ( $\mathrm{n}=4$, 

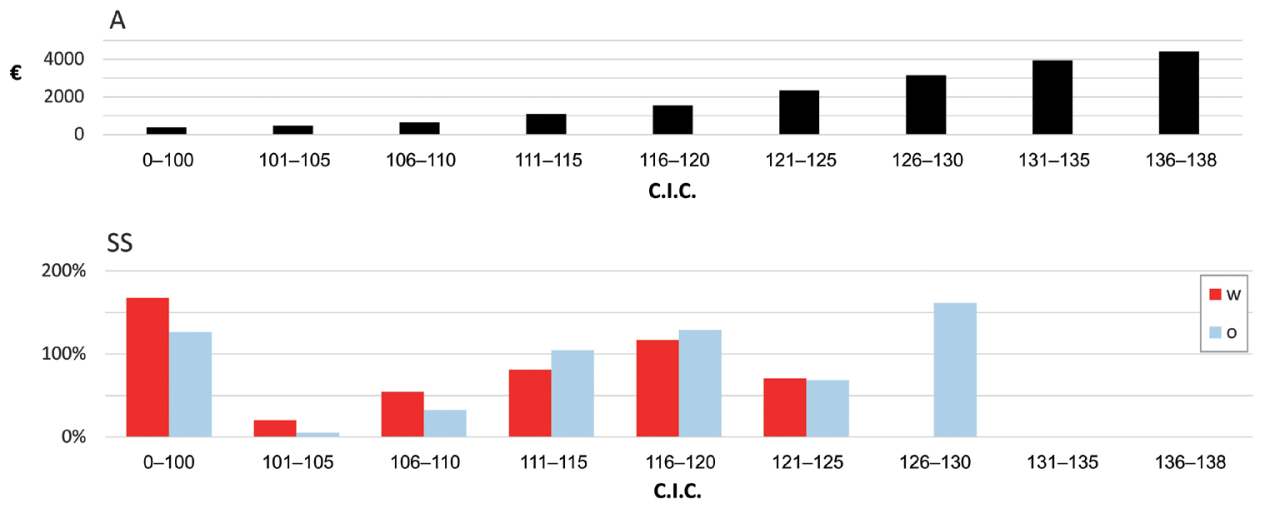

Obr. 7. Závislost' ekonomického zhodnotenia (€) a kategórií C.I.C. diviaka lesného (AnONymus 2019a). SS - porovnanie zmien trofejového rozvrstvenia ulovených diviakov v hodnotených kategóriach medzi obdobiami 2014-2019 vs. 1997-2013; údaje hodnotené bez úhynu. W - pol’ovné revíry s územnou ochranou vlka; $\mathrm{O}$ - ostatné pol'ovné revíry.

zlaté $0 \%$, vlk); PR Kopaniny ( $\mathrm{n}=1$, zlaté $0 \%$, vlk), PR Parilova ( $\mathrm{n}=7$, zlaté $0 \%$, vlk), PR Sninský Kameň ( $n=4$, zlaté $0 \%$, mimo), PR Starina $(n=1$, zlaté $0 \%$, vlk) a PR Veliká $(n=4$, zlaté $25 \%$, mimo). Vzájomný pomer medailových trofejí (Z:S:B) bol 7:12:15 (n=326).

\section{Srnec hôrny (Capreolus capreolus)}

Srnec hôrny je druhým najvýznamnejším loveným druhom (obr. 2A), ktorý sa ale menej výrazným podielom podiel'a na PETV ako diviak (obr. 3,4 ). Porovnaním štandardizovaných dát medzi obdobiami pred a po roku 2014, je pozorovaný relatívne stabilný stav v obidvoch oblastiach s výnimkou nižších tried 80-100 bodov C.I.C., kde je vyhodnotený výraznejší pokles (obr. 9). Hodnotnejšie srnčie trofeje nad 110 bodov C.I.C. (po roku 2014) sú situované prevažne v oblasti mimo územnej ochrany vlka, pričom medailové jedince sú roztrúsene nepravidelne (obr. 9, 10).

Medailových jedincov $(n=22)$ bolo zo všetkých hodnotených jedincov $(n=2.139)$ v období 2014-2019 1,03 \% (z toho zlatých 0,05 \%). V PR Beskýd Snina (n=12, vlk) medailové jedince tvorili $8 \%$, nasleduje PR Hudakov $(n=25$, vlk) s medailovými jedincami na úrovni $8 \%$ a tretí v poradí je PR Jazvec $(n=14$, mimo) s medailovými jedincami na úrovni $7 \%$. Zlatá srnčia trofej $(2 \%)$ bola vykazovaná len v PR Maguriča $(n=46$, mimo). Vzájomný pomer medailových trofejí (Z:S:B) bol 1:5:15 (n=21).

\section{Porovnanie hodnotených oblastí}

Vzájomným porovnaním štandardizovaných dát PETV vybraných druhov v sledovaných oblastiach (obr. 4), a následne porovnaním dát v obdobiach 2014-2019 vs. 1997-2013, je vyhodnotený priemerný nárast v oblasti PR s územnou ochranou vlka na úrovni 178 \% za rok PETV $_{\mathrm{CE}}$ u jelenov, $113 \%$ za rok PETV SS $_{\text {u diviakov a } 173 \% \text { za rok PETV }}$ u srncov (obr. 11). V PR mimo územnej ochrany vlka porovnaním dát v obdobiach 2014-2019 vs. 1997-2013 je vyhodnotený priemerný nárast $\mathrm{v}$ PR bez územnej ochrany vlka na úrovni $155 \%$ za rok PETV $\mathrm{CE}_{\mathrm{C}}$

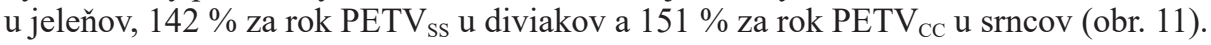


Porovnaním jednotlivých období (2014-2019 vs. 1997-2013) je vyhodnotený takmer na celom území nárast PETV s výraznými disproporciami medzi jednotlivými PR (obr. 13). V PR s územnou ochranou vlka (obdobie 2014-2019; obr. 12) bola priemerná hodnota PETV na úrovni $249 € / \mathrm{rok} / \mathrm{km}^{2}\left(\mathrm{SD} 69 € / \mathrm{rok} / \mathrm{km}^{2}\right)$ a v území mimo územnej ochrany bola priemerná hodnota PETV $185 € / \mathrm{rok} / \mathrm{km}^{2}$ (SD $8 € / \mathrm{rok} / \mathrm{km}^{2}$ ). V období po zavedení územnej ochrany vlka boli vyhodnotené dve výraznejšie zmeny (obr. 12) v PR s územnou ochranou vlka a to výrazný nárast v sezóne 2016/2017 (252 \%) a následný prepad až na úroveň 131% v sezóne 2019/2020 (obr. 4). V PR s územnou ochranou vlka (obdobie 2014-2019) boli v zhodnocovaní lovu najlepší PR Stavlinec s PETV $802 € / \mathrm{rok} / \mathrm{km}^{2}$ (SD $553 € / \mathrm{rok} / \mathrm{km}^{2}$ ), d’alší je PR Jeseník s PETV $534 €$ / rok $/ \mathrm{km}^{2}\left(\mathrm{SD} 296 € / \mathrm{rok} / \mathrm{km}^{2}\right)$ a tretí PR Hudakov s PETV $508 € / \mathrm{rok} / \mathrm{km}^{2}\left(\mathrm{SD} 335 € / \mathrm{rok} / \mathrm{km}^{2}\right)$.

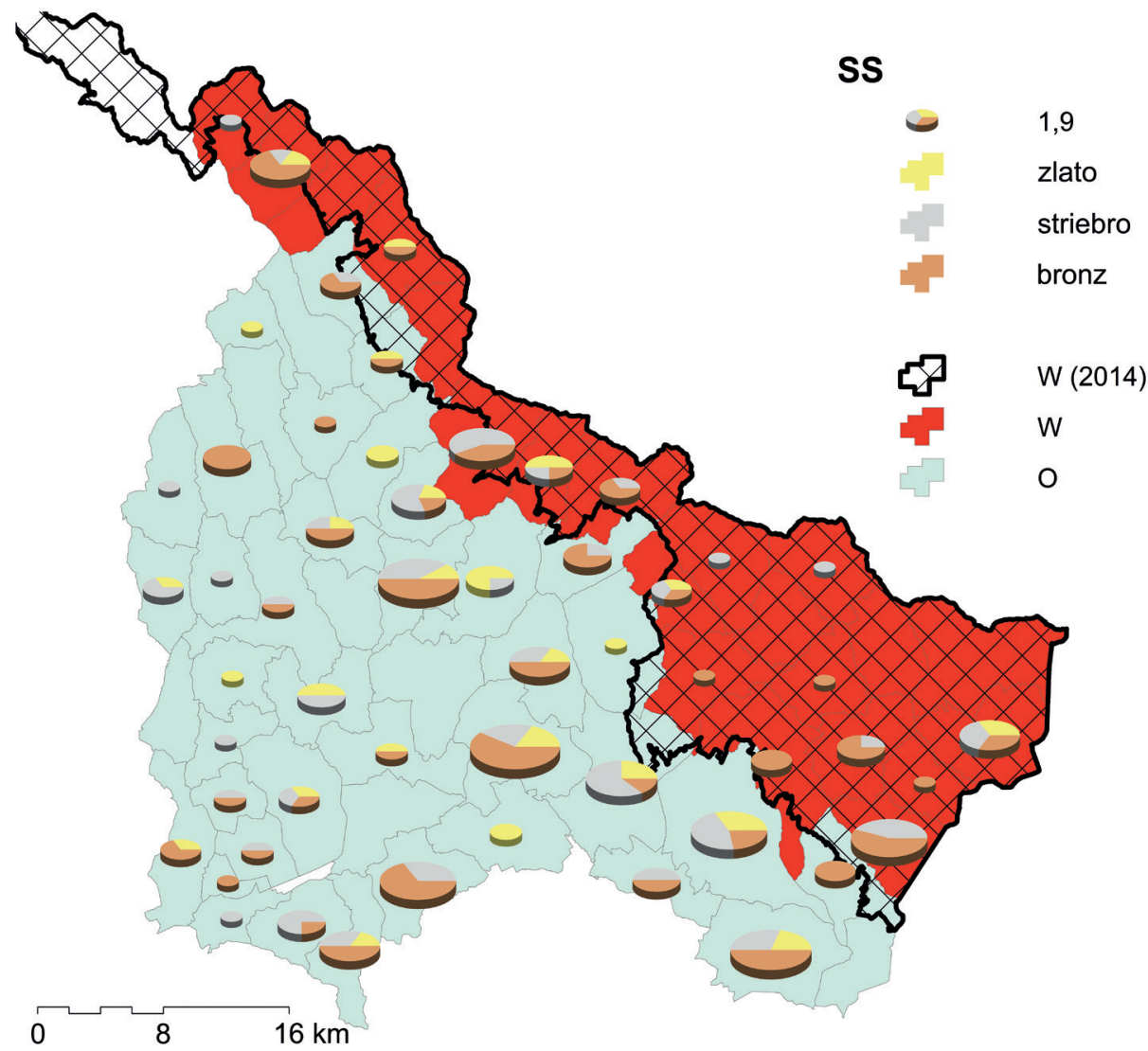

Obr. 8. Disperzia ulovených medailových jedincov diviaka lesného (SS) v rámci hodnotených oblastí (2014-2019); spracovávané dáta bez úhynu. 1,9 - mierka symbolu =1,9 medaily pre pol'ovný revír; W (2014) - oblast' s prísnou ochranou vlka od roku 2014; W - pol'ovné revíry s územnou ochranou vlka; $\mathrm{O}$ - ostatné pol'ovné revíry. 

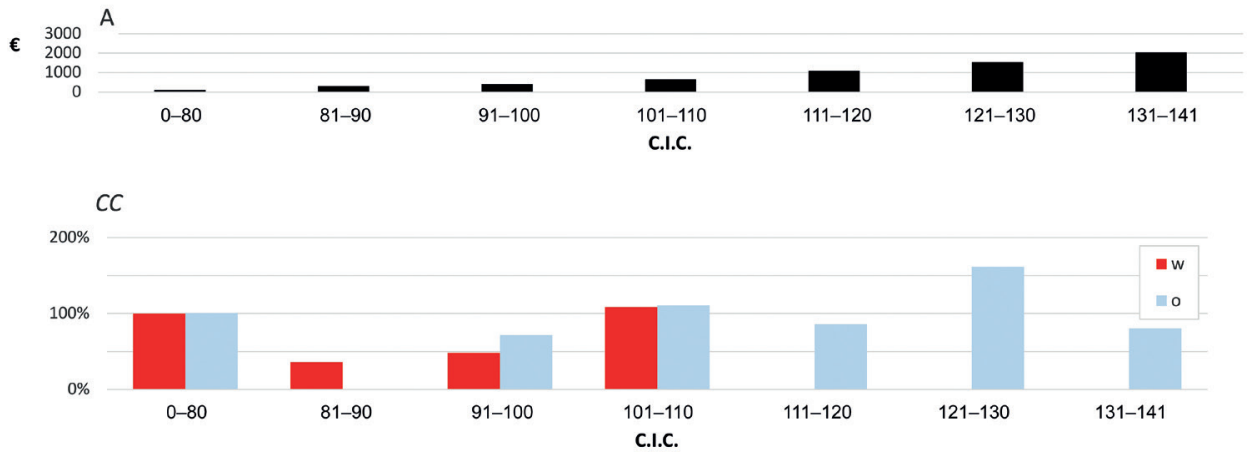

Obr. 9. Závislost' ekonomického zhodnotenia (€) a kategórií C.I.C. srnca hôrneho (ANONYmus 2019a). $\mathrm{CC}$ - porovnanie zmien trofejového rozvrstvenia ulovených srncov v rámci hodnotených kategórií medzi obdobiami 2014-2019 vs. 1997-2013; údaje hodnotené bez úhynu. W - pol’ovné revíry s územnou ochranou vlka; $\mathrm{O}$ - ostatné pol'ovné revíry.

Výrazne najslabšie hodnoty PETV boli zistené v PR Kolodnik (obr. 13) s hodnotou PETV $75 € /$ rok $/ \mathrm{km}^{2}$ (SD $\left.41 € / \mathrm{rok} / \mathrm{km}^{2}\right)$.

V PR mimo územnej ochrany vlka (obdobie 2014-2019) boli najlepší PR Výravka s PETV $457 € / \mathrm{rok} / \mathrm{km}^{2}$ (SD $134 € / \mathrm{rok} / \mathrm{km}^{2}$ ), d'alší PR Jazvec s PETV $391 € / \mathrm{rok} / \mathrm{km}^{2}$ (SD $146 € / \mathrm{rok} /$ $\mathrm{km}^{2}$ ) a tretí PR Tisovec s PETV $372 € / \mathrm{rok} / \mathrm{km}^{2}$ (SD $105 € / \mathrm{rok} / \mathrm{km}^{2}$ ). Výrazne najslabšie hodnoty PETV boli zistené v PR Pel'hy na úrovni $44 € / \mathrm{rok} / \mathrm{km}^{2}$ (SD $35 € / \mathrm{rok} / \mathrm{km}^{2}$ ).

\section{Úhyn}

Úhyn mal výraznejší vplyv na PETV v PR s územnou ochranou vlka na priemernej úrovni $45 € /$ $\mathrm{rok} / \mathrm{km}^{2}$ (rozsah 0-159 €/rok/ $\mathrm{km}^{2}$ ) a v PR bez územnej ochrany vlka bolo PETV na priemernej úrovni $21 € / \mathrm{rok} / \mathrm{km}^{2}$ (rozsah $0-47 € / \mathrm{rok} / \mathrm{km}^{2}$ ). V PR s územnou ochranou vlka boli vyhodnotené dva výrazné nárasty úbytku PETV v rokoch $2006\left(139 € / \mathrm{rok} / \mathrm{km}^{2}\right)$ a $2016\left(159 € / \mathrm{rok} / \mathrm{km}^{2}\right)$ a nulové hodnoty úbytku PETV v rokoch 2000, 2002-2005 a 2010.

\section{DISKUSIA}

\section{Jelen̆ lesný (Cervus elaphus)}

$S$ výnimkou juhozápadných $P R(n=7)$, ktoré patria do oblasti s chovom srnca, ostatné $P R(n=58)$ patria do pol'ovnej oblasti s chovom jeleňa (ANONYMus 2009d). Jeleň je najvýznamnejším druhom pol'ovnej zveri (LEHOCKÝ \& KURIC 2007), čo bolo vyhodnotené v oblasti už aj inými metódami (ŠTofík et al. 2019).

Pri vyhodnocovaní nižších tried C.I.C. (100-170) došlo medzi porovnávanými obdobiami k výraznému poklesu, avšak tieto hodnoty pravdepodobne odrážajú zmeny v legislatíve (ANONYMUS 2009c), podl'a ktorých obvodná komisia alebo ústredná hodnotitel'ská komisia vyplní bodovaciu tabul'ku na hodnotenie pol'ovníckych trofejí až v prípade jeleňa od 170 bodov C.I.C. To potvrdzuje aj výrazný nárast $\mathrm{v}$ oboch oblastiach v triede do 100 bodov C.I.C., do ktorej pravdepodobne vzhl'adom k nehodnoteniu (nevypĺn̆aniu bodovacej tabul'ky) prepadli po roku 
2009 trofeje do 170 bodov C.I.C. Na druhej strane, výraznejší nárast nastal takmer vo všetkých najhodnotnejších kategóriách C.I.C. nad 170 bodov v PR s územnou ochranou vlka, čo môžeme považovat' za kvalitatívne zlepšenie oproti obdobiu pred zavedením územnej ochrany vlka. Nízke hodnoty $P E T V_{C E} V$ niektorých $P R$ nám však naznačujú nevyužitý potenciál týchto $P R$.

Ak vezmeme do úvahy len medailové jedince z obdobia 2014-2019, v hodnotenom území predstavoval počet ulovených trofejových jeleňov na jedného uloveného medailového zlatého jeleňa počet 195, čo je nárast oproti minulosti (HeLl et al. 1983), avšak tieto hodnoty sú nižšie ako vo vybranej časti územia (150) v okrese Snina (ŠTofík et al. 2019). V Mad'arsku tvorili medailové jedince 32-36 \% (zlaté $4 \%$ ), na Slovensku 5,3\% (zlaté 0,17\%), pričom na východe Slovenska 5,2 \% (zlaté 0,27 \%) z celkového úlovku (Hell et al. 1983). V hodnotenom území

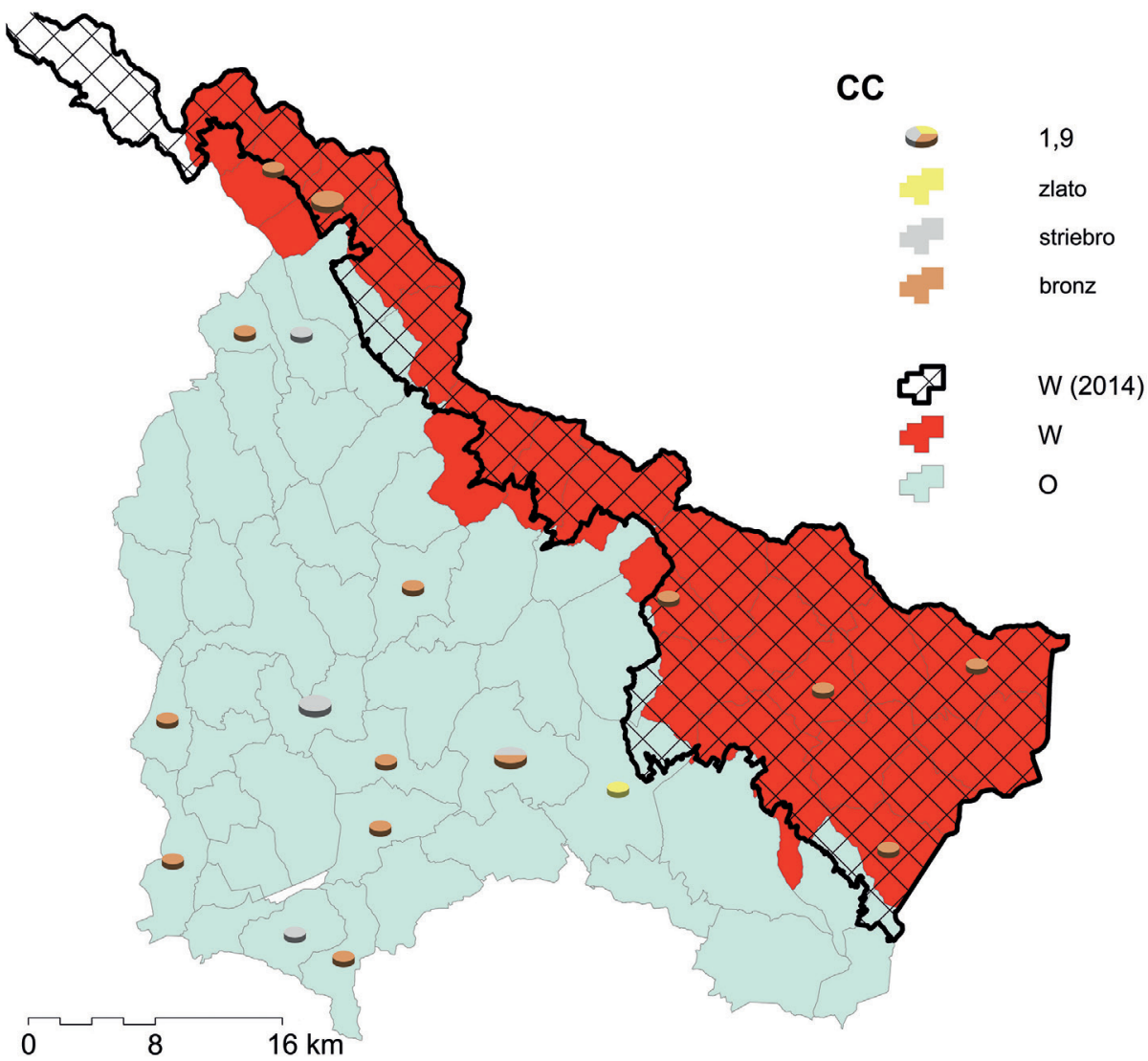

Obr. 10. Disperzia ulovených medailových jedincov srnca (CC) v hodnotených oblastiach (2014-2019); dáta spracované bez úhynu. 1,9 - mierka symbolu $=1,9$ medaily pre pol'ovný revír; $\mathrm{W}(2014)$ - oblast' s územnou ochranou vlka od roku 2014; W - pol'ovné revíry s územnou ochranou vlka; O - ostatné pol'ovné revíry. 


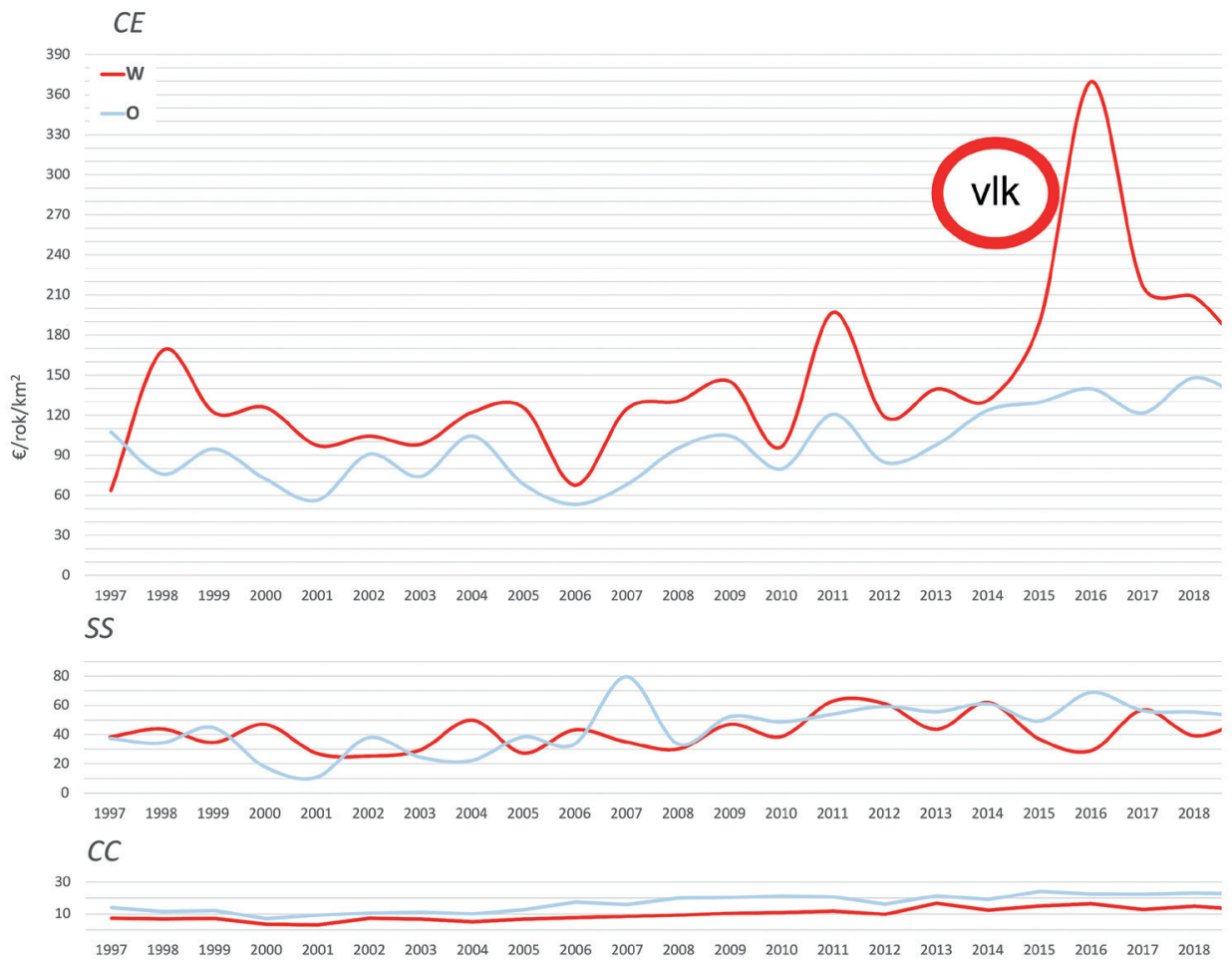

Obr. 11. Porovnanie trendov potencionálnej ekonomickej trofejovej významnosti (PETV) úbytku vybraných druhov zveri ( $\left.€ / \mathrm{rok} / \mathrm{km}^{2}\right)$; dáta spracované s úhynom. CE - jeleň lesný Cervus elaphus; $\mathrm{SS}$ - diviak lesný Sus scrofa; CC - srnec hôrny Capreolus capreolus. W - pol'ovné revíry s územnou ochranou vlka; $\mathrm{O}$ - ostatné pol'ovné revíry.

došlo oproti minulosti k výraznejšiemu kvalitatívnemu posunu (medailových $12 \%$ a zlatých $0,51 \%$, avšak niektoré PR dosahujú omnoho vyššie hodnoty. Ak porovnáme kvalitatívne hodnoty (počet zlatých z trofejových) oboch hodnotených oblastí, tie zaostávajú za oblast'ou CHPO Pol'ana (napr. vlk - $6 \%$, mimo - 3 \% vs. Detva - 18 \%; KAšTIER et al. 2013). Avšak v jednotlivých PR sú tieto hodnoty výrazne vyššie: PR Zubenské $33 \%(n=3$, mimo), PR Bil'anka $33 \%(n=3$, mimo), PR Polom $25 \%(n=4$, mimo), PR Poloň $25 \%(n=4$, vlk) a PR Kyčera 20 \% (n=5, vlk). No boli aj PR s vyšším zastúpením medailových jedincov, no s nižším počtom (prípadne bez) zlatých trofejí. Tieto nižšie hodnoty v zastúpení zlatých trofejí môžu súvisiet's nízkym vekom lovených jedincov, ktorý bol vyhodnotený v rámci územia (ŠTofík et al. 2019) a je výrazne nižší, ako by mal byt' k zabezpečeniu kvalitnejších medailových trofejí (napr. LeHOCKÝ \& KuRIC 2007, RivRUd et al. 2013). Tu môže zohrávat' dôležitú úlohu kvalitný genofond jelenov (PAULE \& KRIŠTA 1984), čo viedlo v minulosti k vyhláseniu Pol'any za oblast' so zvláštnou pozornost'ou - chránenú pol'ovnú oblast' (KAŠTIER et al. 2013). Túto ideu o kvalitnom genofonde hodnoteného územia podporujú aj údaje zo susedného Pol'ska, kde 
5 z 10 najcennejších jeleních zlatých trofejí pochádza z oblasti susedných Bieszczad (PERzANOWSKI \& KRZAKIEWICZ 2000). Porovnaním pomeru trofejí (1:6:17) s hodnotami z účelového PR Technickej univerzity (1:16:56) vo Zvolene (GARAY \& GARAY 2007), je vidno v súčasnosti výrazne kvalitnejší potenciál hodnotenej oblasti.

\section{Diviak lesný (Sus scrofa)}

V nižších triedach C.I.C. (100-110 bodov) došlo k výraznej zmene v oboch hodnotených oblastiach, avšak aj tu ide pravdepodobne o odozvu na zmeny v legislatíve (ANONYMUS 2009c), podl'a ktorej obvodná komisia alebo ústredná hodnotitel'ská komisia vyplní bodovaciu tabul'ku na hodnotenie pol'ovníckych trofejí u diviakov až od 110 bodov C.I.C.

Napriek tomu, že napr. v Mad’arsku výrazne narastá význam diviaka na úkor jeleňa (BLEIER et al. 2013), v oboch oblastiach hodnoteného územia na východnom Slovensku výraznejšie medzi obdobiami stúpa kvalitatívny potenciál jeleňov. V oblasti mimo územnej ochrany vlka je však v posledných rokoch (2014-2019) vyhodnotený výraznejší nárast vplyvu PETV SS $_{\text {ako }}$ v oblasti s územnou ochranou.

\section{Srnec hôrny (Capreolus capreolus)}

V nižších triedach C.I.C. (80-100 bodov) došlo k výraznej zmene, avšak to je pravdepodobne opät' odozva na zmenu vo vyhláške (ANONYMus 2009c), podl'a ktorej obvodná komisia alebo ústredná hodnotitel'ská komisia vyplní bodovaciu tabul'ku na hodnotenie pol'ovníckych trofejí u srnca najmenej od 105 bodov C.I.C. Slovenské cenníky (napr. ANONYMUs 2017, 2018a, b,

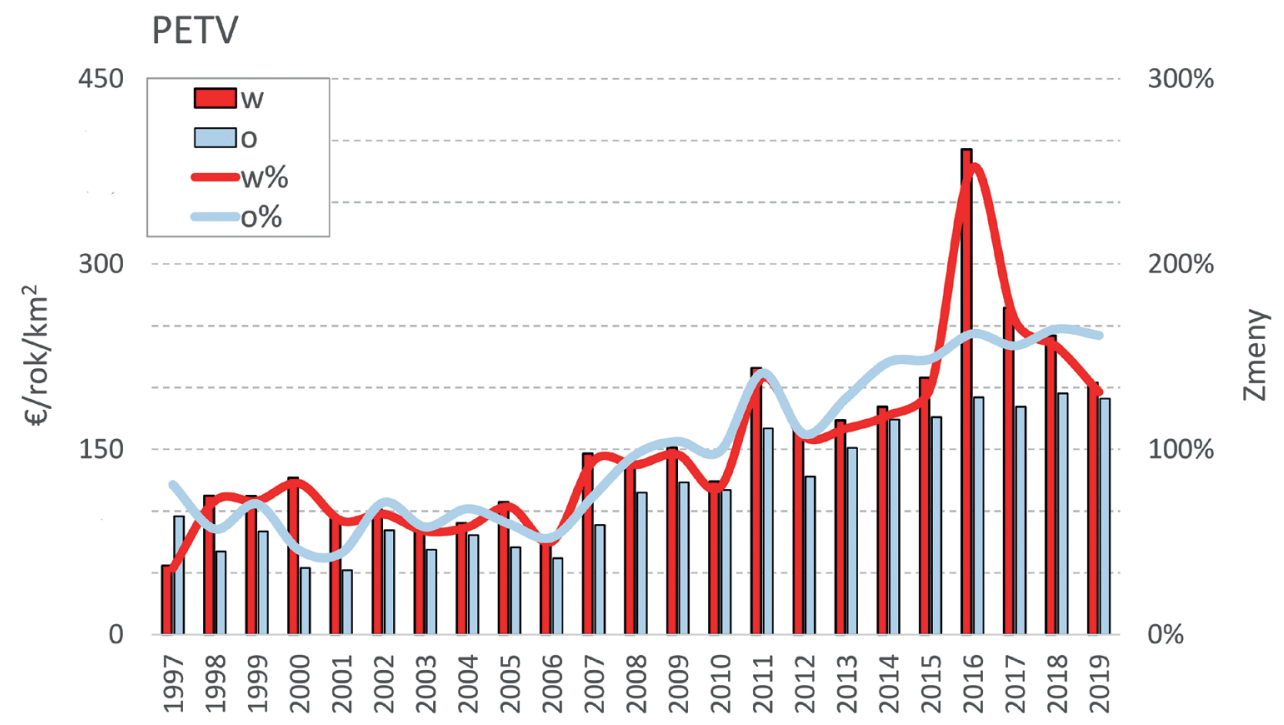

Obr. 12. Porovnanie štandardizovaného (priemer $€ / \mathrm{rok} / \mathrm{km}^{2}$ ) potencionálneho ekonomického zhodnotenia trofejových kopytníkov (PETV) a jeho relatívnych zmien (\%) v hodnoteném období (1997-2019) v jednotlivých oblastiach; dáta spracované bez úhynu. W - pol'ovné revíry s územnou ochranou vlka; $\mathrm{O}$ - ostatné pol'ovné revíry. 


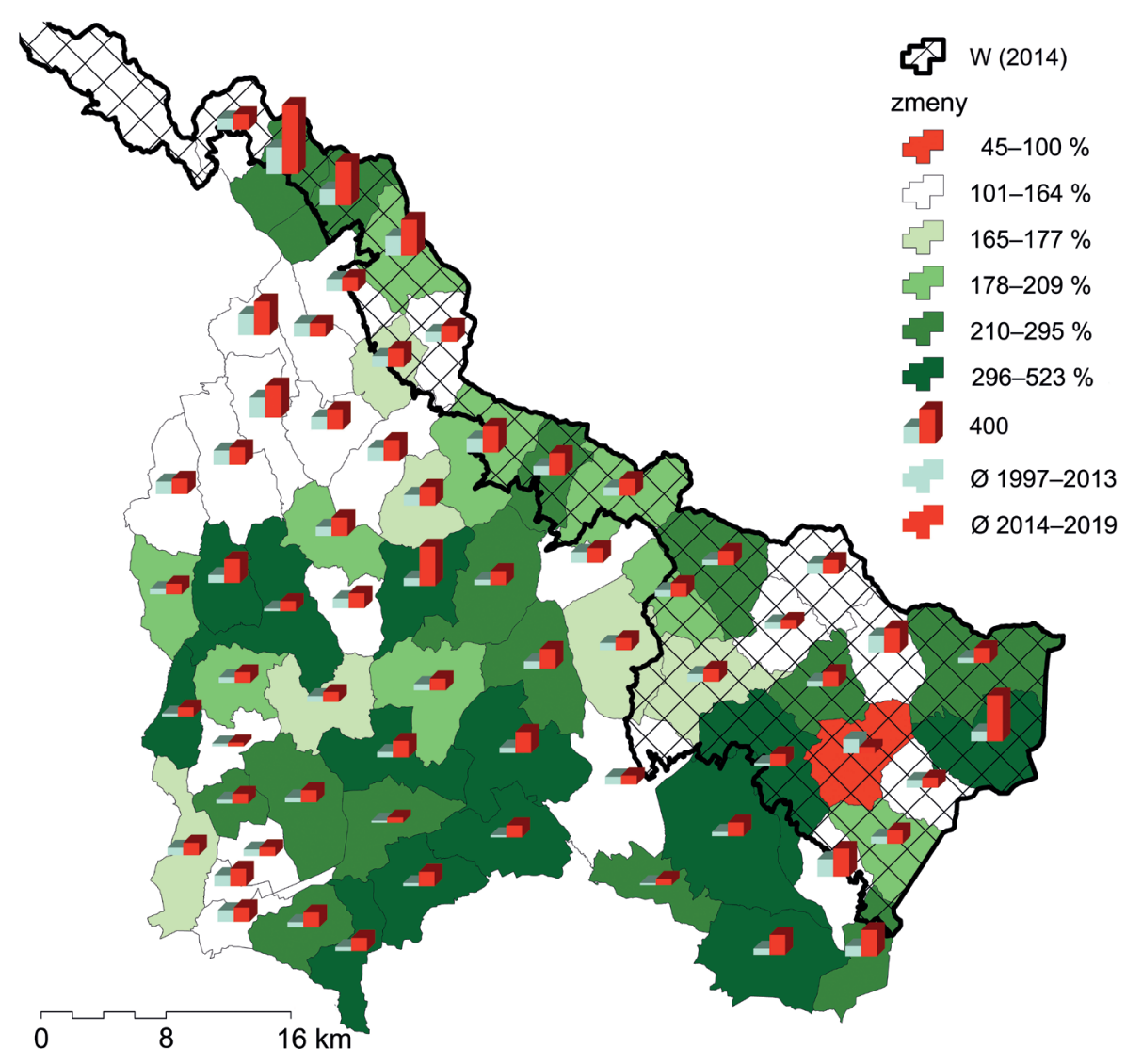

Obr. 13. Priestorová disperzia potencionálneho štandardizovaného zhodnotenia jednotlivých pol'ovných revírov PETV - priemerné hodnoty $\left(€ / \mathrm{rok} / \mathrm{km}^{2}\right)$ a vyhodnotenie relatívnych zmien v období 2014-2019 vs. 1997-2013; dáta spracované bez úhynu.

2019 b, c) pracujú pri odstrelovom poplatku prevažne s hmotnost'ou. Hmotnost' je ale jednou z veličín u srnčích trofejí, pri ktorej bodové ohodnotenie môže byt' zmanipulované (SCHERER 2014), avšak objem trofejí je vo väčšine prípadov dobrým indikátorom hodnoty trofeje v bodoch C.I.C. (UrošEvić et al. 2017).

\section{Ostatné druhy kopytníkov}

Práca len okrajovo zahŕňa minoritné druhy, ktoré sa chovajú vo zverniciach (muflón a daniel), mimo PR s územne zabezpečenou ochranou vlka a tvoria len minoritnú čast' PETV jednotlivých PR. V hodnotenom území žije d'alší druh kopytníka, zubor hôrny (PČOLA \& ADAMEC 2005), ktorý je chráneným druhom (ANONYMus 2003b) a na PETV sa priamo nepodiel'a. Treba však podotknút', že v PR kde sa zubor vyskytuje vo vol'nej prírode, je možné pozorovat' nevýznamné zníženie medailových trofejí jeleňa. Takýto vplyv však nebol vyhodnotený pri relativizovanom 
ekonomickom zhodnotení (ŠTofík et al. 2019) nezameranom na kvalitu trofejí. Obdobné výstupy boli pozorované aj v Yelowstone porovnaním dvoch období (1967-1970 vs. 1986-1988), kde bolo vyhodnotené trojnásobné zvýšenie stavov kopytníkov, pričom zmeny v náraste bizónov a jeleňov vzájomne pozitívne korelovali (SINGER \& NoRLAND 1994).

\section{PETV - potenciálny ekonomický význam trofejí}

V hodnotenom území je dlhodobo pozorovaný nárast PETV, bez ohl'adu na úhyn a zmeny v legislatíve (ANONYmus 2009c). Výkyvy v PETV v rámci úhynu môžu byt' v prvom období odozvou na legislatívnu nejasnost' po zavedení zákona o ochrane prírody (ANONYMUs 2002b), čo mohlo viest' k nenahlasovaniu úhynov, prípadne to mohli spôsobit' iné okolnosti, ktoré mali vplyv na obidve hodnotené oblasti.

Táto práca porovnáva aj PETV v rámci jednotlivých $P R$, kde sú vyhodnocované výrazné disproporcie pri zhodnocovaní potenciálu jednotlivých PR, čo len makroskopicky zachytáva zákon o pol'ovníctve cez skupiny lesných typov a pol'nohospodársku pôdu (ANONYMUs 2009c), no nezachytáva ostatné dôležité antropogénne vplyvy, v rámci ktorých napr. aj použitie nevhodného krmiva môže viest' k negatívnym výsledkom pre pol'ovníkov, vlastníkov a zvieratá (FELTON et al. 2017). No doplnkové kŕmenie je možné použit' aj na zlepšenie zimného prežitia (DoENIER et al. 1997) a zvýšenie reprodukčného úspechu zvierat (RoBB et al. 2008). Na druhej strane okrem rozdielov v biotopoch zohráva pri formovaní potravy jeleňov dôležitú úlohu riziko predácie (CHURSKI et al. 2020), čo naznačuje porovnávanie hodnotených oblastí.

Stavy kopytníkov sú v Európe na vysokej úrovni a majú stúpajúci trend (APOLlonio et al. 2010, KONÔPKA \& KAŠTIER 2013, RIVRUD et al. 2013). PETV medzi obdobiami stúpa a najvýraznejšie sa na tom podiel'a u oboch hodnotených oblasti jelene. PETV aj v súčasnosti (2014-2019) výrazne kolíše (44-802 €/rok $/ \mathrm{km}^{2}$ ), pričom priemerné hodnoty PETV v oblasti s územnou ochranou vlka predstavujú $249 € / \mathrm{rok} / \mathrm{km}^{2}$ a mimo $185 € / \mathrm{rok} / \mathrm{km}^{2}$. V dohl'adaných prípadoch nájmu tieto hodnoty (PETV) výrazne prevyšujú hodnotu nájmu $132 € / \mathrm{rok} / \mathrm{km}^{2}$, prípadne $99 € /$ $\mathrm{rok} / \mathrm{km}^{2}$, a to aj napriek tomu, že sa jedná len o jednu z mnohých ekonomických aktivít PR (LEHOCKÝ \& KURIC 2007). Na druhej strane disproporcie medzi jednotlivými PR môžu súvisiet' s úživnost'ou revíru (ANONYMUS 2009c), geomorfologickými podmienkami, predáciou (CHURSKI et al. 2020), ale môžu byt' ovplyvňované negatívne aj pytliactvom (HeLl et al. 2004, ŠTofík 2010), vlečkovým prikrmovaním (LEHOCKÝ \& KURIC 2007), zlým hospodárením (ŠTOFík et al. 2019) apod. Na území Slovenska sú negatívne vplyvy v súvislosti s prikrmovaním (MösT et al. 2015) od roku 2020 čiastočne obmedzené v národných parkoch (severovýchodná čast'

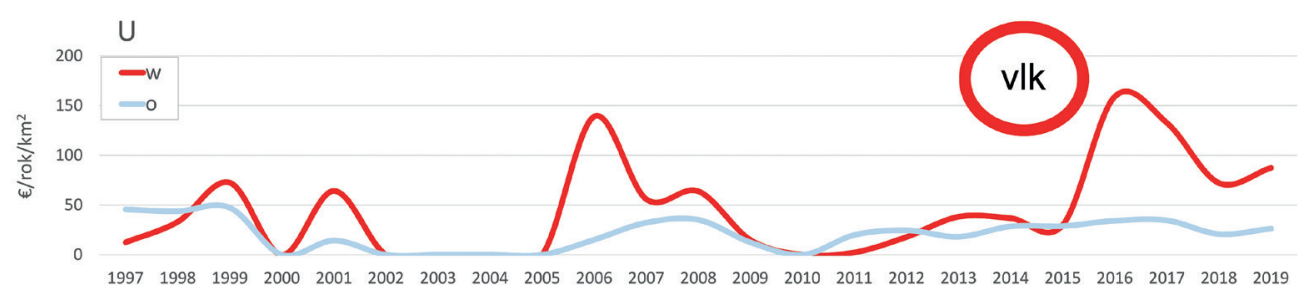

Obr. 14. Porovnanie vplyvu úhynu - U $\left(€ /\right.$ rok $\left./ \mathrm{km}^{2}\right)$ na potencionálne ekonomické zhodnotenie trofejových kopytníkov (PETV). W - pol’ovné revíry s územnou ochranou vlka; $\mathrm{O}$ - ostatné pol’ovné revíry. 
hodnoteného územia), kde vnadenie alebo prikrmovanie zveri (okrem prikrmovania senom, letninou a trávnou alebo d’atelinotrávnou silážou) je podmienené súhlasom orgánu ochrany prírody (ANONYMUS 2002b).

Bodová hodnota C.I.C.

Samotný zákon o pol'ovníctve (ANONYMUs 2009c) pracuje s hodnotami C.I.C., no niektoré kategórie (napr. jeleň 0-170, diviak 0-110, daniel 0-160, muflón 0-185 a srnec 0-105 bodov C.I.C.) sú nepriamo vylúčené z hodnotenia a obvodná komisia alebo ústredná hodnotitel'ská komisia ich nemusí doplnit' do bodovacej tabul'ky.

Vzhl'adom k tomu, že slovenské cenníky (napr. ANONYMUs 2017, 2018a, b, 2019b, c) pracujú pri odstrelovom poplatku prevažne s hmotnost'ou trofeje, bol k vyhodnoteniu potenciálneho ekonomického zhodnotenia trofejových kopytníkov využitý český katalóg (ANONYMUs 2019a), ktorý spracovával cenník pre lov cez hodnoty C.I.C. Aj nezverejňovaním dát o hmotnosti trofejí dochádza $\mathrm{k}$ strate údajov, a $\mathrm{v}$ nadväznosti $\mathrm{k}$ tomu aj $\mathrm{k}$ strate údajov o potenciálnom ekonomickom zhodnotení úlovkov, ktoré sa nedostávajú do vyhodnotenia z jednotlivých prehliadok od roku 2000 (ANONYMUs 20002001, 2002a, 2003a, 2004, 2005, 2006, 2007, 2008, 2009a, 2010, 2011, 2012, 2013, 2014, 2015, 2016, 2017b, 2018c, 2019d, 2020a). Týmto spôsobom je vlastník ukrátený o možnost' efektívnejšieho zhodnocovania majetku a o možnost' požadovat' primeranú náhradu, ktorá sa v súčasnosti vypočítava na základe bonity (ANONYMUs 2009b, c) a nie na základe potenciálu majetku. Touto praxou stráca vlastník (aj štát) prehl'ad o hospodárení subjektov na majetku, a v nadväznosti na to sa stráca prehl'ad aj o ekonomickom potenciáli majetku. Zhodnocovaním trofejí cez váhu sa stráca prehl'ad o chove v medzinárodnom meradle vzhl'adom k tomu, že na medzinárodné výstavy sa dostávajú len významnejšie pol'ovnícke trofeje (ANONYMUs 2009c), ktoré je však možné docielit’ aj neštandardnými metódami (HeLL et al. 2009, SCHERER 2014).

\section{ZÁVER}

Predkladaná práca prináša nový pohl'ad na porovnávanie trofejového potenciálu oblastí, PR ako aj jednotlivých druhov. Zároveň poukazuje na vplyvy legislatívnych zmien (z dlhodobého hl'adiska) na vyhodnocovanie pol'ovného hospodárenia, a nepriamo na (ne)dostupnost' relevantných dát (hmotnost') a absenciu otvorených metód porovnávania až na úroveň PR. Vlastníci (aj štát) by mali mat' prehl'ad (ak majú záujem) o tom, ako sa zhodnocuje majetok a v nadväznosti $\mathrm{k}$ tomu by mali za nájom dostávat' primeranú náhradu. Zavedením štandardizácie v rámci týchto analýz, bol hodnotený ekonomický potenciál PR a hodnotených oblastí, pričom je možné širokospektrálne využitie získaných údajov. Vzhl'adom k dostupným údajom sa dá predpokladat', že zavedenie územnej ochrany vlka nemalo v krátkodobom horizonte (2014-2019) negatívny vplyv na trend PETV, avšak u jeleňov je pozorované výrazne rozkolísanie hodnôt pri porovnaní s predchádzajúcim obdobím. U všetkých hodnotených druhov má PETV vzostupný charakter, pričom celkovo má najvýznamnejší vplyv na jeleňa, nasleduje diviak a srnec.

\section{Pod'a kovani e}

Táto práca vznikla aj vd’aka projektu Štátnej ochrany prírody SR "Realizácia programov starostlivosti o vel'ké šelmy na Slovensku” (ITMS: 310011L489) v rámci OP KŽP. Za poskytnuté podklady d'akujem Silvii PerinAJOveJ, za vecné zhodnotenie MS d'akujem Jozefovi BučKovi a za pomoc s prekladom d'akujem Zuzane BARTUŠOvEJ. 


\section{LITERATÚRA}

ANONYmus, 1992: Ústavný zákon č. 460/1992 Zb. P.: 7. In: AnONYmus (ed.): Ústava Slovenskej republiky. Slovenská národná rada, Bratislava, 53 pp.

ANONYMUs, 1998: Katalóg trofejovej zveri hodnotenej na regionálnej chovatel'skej prehliadke za pol’ovnicku sezónu 1997/1998 pre okresy Humenné, Snina a Medzilaborce. Regionálna organizácia Slovenského pol’ovníckeho zväzu, Humenné, 32 pp.

ANONYMUs, 1999: Katalóg trofejovej zveri hodnotenej na regionálnej chovatel'skej prehliadke za pol’ovnicku sezónu 1998/1999 pre okresy Humenné, Snina a Medzilaborce. Regionálna organizácia Slovenského pol'ovníckeho zväzu, Humenné, 32 pp.

ANONYMUs, 2000: Katalóg trofejovej zveri hodnotenej na regionálnej chovatel'skej prehliadke za pol'ovnicku sezónu 1999/2000 pre okresy Humenné, Snina a Medzilaborce. Regionálna organizácia Slovenského pol'ovníckeho zväzu, Humenné, 32 pp.

ANONYMUs, 2001: Katalóg trofejovej zveri hodnotenej na regionálnej chovatel'skej prehliadke za pol’ovnicku sezónu 2000/2001 pre okresy Humenné, Snina a Medzilaborce. Regionálna organizácia Slovenského pol’ovníckeho zväzu, Humenné, 26 pp.

ANONYMUS, 2002a: Katalóg trofejovej zveri hodnotenej na regionálnej chovatel'skej prehliadke za pol’ovnicku sezónu 2001/2002 pre okresy Humenné, Snina a Medzilaborce. Regionálna organizácia Slovenského pol'ovníckeho zväzu, Humenné, 28 pp.

ANONYmus, 2002b: 543. Zákon z 25. júna 2002 o ochrane prírody a krajiny. Pp.: 1-117. In: ANONYMus (ed.): Zbierka zákonov Slovenskej republiky. Ročnik 2002. Národná rada Slovenskej republiky, Bratislava, $117 \mathrm{pp}$.

ANONYMus, 2003a: Katalóg trofejovej zveri hodnotenej na regionálnej chovatel'skej prehliadke za pol'ovnicku sezónu 2002/2003 pre okresy Humenné, Snina a Medzilaborce. Regionálna organizácia Slovenského pol'ovníckeho zväzu, Humenné, 28 pp.

ANONYmus, 2003b: Vyhláška č. 24/2003 Z. z. Vyhláška Ministerstva životného prostredia Slovenskej republiky, ktorou sa vykonáva zákon č. 543/2002 Z. z. o ochrane prírody a krajiny. P.: 218. In: ANONYMUS (ed.): Zbierka zákonov Slovenskej republiky. Ročník 2003. Národná rada Slovenskej republiky, Bratislava, $3146 \mathrm{pp}$.

ANONYMus, 2004: Katalóg trofejovej zveri ulovenej v roku 2003. Regionálna organizácia Slovenského pol'ovníckeho zväzu, Humenné, 46 pp.

ANONYMus, 2005: Katalóg trofejovej zveri ulovenej v roku 2004. Regionálna organizácia Slovenského pol’ovníckeho zväzu, Humenné, 38 pp.

ANONYMus, 2006: Katalóg trofejovej zveri ulovenej v roku 2005. Regionálna organizácia Slovenského pol’ovníckeho zväzu, Humenné, 38 pp.

ANONYMus, 2007: Katalóg trofejovej zveri hodnotenej na regionálnej chovatel'skej prehliadke za pol'ovnicku sezónu 2006/2007 pre okresy Humenné, Snina a Medzilaborce. Regionálna organizácia Slovenského pol’ovníckeho zväzu, Humenné, 38 pp.

ANONYMus, 2008: Katalóg trofejovej zveri ulovenej v roku 2007-2008. Regionálna organizácia Slovenského pol'ovníckeho zväzu, Humenné, 30 pp.

ANONYMus, 2009a: Katalóg trofejovej zveri ulovenej v roku 2008-2009. Regionálna organizácia Slovenského pol'ovníckeho zväzu, Humenné, 30 pp.

ANONYMUs, 2009b: Zákon č. 274/2009 Z. z. Zákon o pol’ovníctve a o zmene a doplnení niektorých zákonov. Pp.: 5-6. In: AnONYmus (ed.): Zbierka zákonov Slovenskej republiky. Ročník 2009. Národná rada Slovenskej republiky, Bratislava, $37 \mathrm{pp}$.

ANONYMus, 2009c: Vyhláška č. 344/2009 Z. z. Vyhláška Ministerstva pôdohospodárstva Slovenskej republiky, ktorou sa vykonáva zákon o pol’ovníctve. Pp.: 1-113. In: ANONYMUs (ed.): Zbierka zákonov Slovenskej republiky. Ročník 2009. Národná rada Slovenskej republiky, Bratislava, 113 pp.

ANONYmus, 2010: Katalóg trofejovej zveri ulovenej v roku 2009-2010. Regionálna organizácia Slovenského pol'ovníckeho zväzu, Humenné, 42 pp. 
ANONYMUs, 2011: Katalóg trofejovej zveri hodnotenej na regionálnej chovatel'skej prehliadke za pol'ovnicku sezónu 2010/2011 pre okresy Humenné, Snina a Medzilaborce. Regionálna organizácia Slovenského pol'ovníckeho zväzu, Humenné, 29 pp.

ANONYMUs, 2012: Katalóg trofejovej zveri hodnotenej na regionálnej chovatel'skej prehliadke za pol'ovnícku sezónu 2011/2012 pre okresy Humenné, Snina a Medzilaborce. Regionálna organizácia Slovenského pol’ovníckeho zväzu, Humenné, 32 pp.

ANONYmus, 2013: Katalóg trofejovej zveri ulovenej v sezóne 2012-2013. Slovenská pol'ovnícka komora a Slovenský pol'ovnícky zväz, Humenné, 63 pp.

ANONYmus, 2014: Katalóg trofejovej zveri ulovenej v sezóne 2013-2014. Slovenská pol'ovnícka komora a Slovenský pol'ovnícky zväz, Humenné, 54 pp.

Anonymus, 2015: Katalóg z chovatel'skej prehliadky trofejí. Pol'ovnícka sezóna 2014/2015. Okresná pol'ovnícka komora, Humenné, 56 pp.

Anonymus, 2016: Katalóg z chovatel'skej prehliadky trofeji. Pol’ovnícka sezóna 2015/2016. Okresná pol'ovnícka komora, Humenné, 60 pp.

AnONymus, 2017a: Cenník pre poplatkový lov zveri pol'ovnými host'ami platnýod 19. 10. 2017. Technická univerzita vo Zvolene, Vysokoškolský lesnícky podnik, Zvolen, 11 pp.

Anonymus, 2017b: Katalóg z chovatel'skej prehliadky trofejí. Pol'ovnícka sezóna 2016/2017. Okresná pol'ovnícka komora, Humenné, 60 pp.

AnONYmus, 2018a: Cenník pre lov pol'ovníckych hostí v pol'ovnom revíri spoločnosti Mestské lesy Banská Štiavnica. Mestské lesy Banská Štiavnica, spol. s r.o., Banská Štiavnica, 5 pp.

AnONYmus, 2018b: Cennik pre lov zveri v pol'ovnickej sezóne 2019/2020. Lesy Slovenskej republiky, š. p., Banská Bystrica, 28 pp.

ANONYMus, 2018c: Katalóg z chovatel'skej prehliadky trofejí. Pol'ovnícka sezóna 2017/2018. Okresná pol’ovnícka komora, Humenné, 60 pp.

ANONYmus, 2019a: Ceník poplatkových loví (1.4.2019-31.3. 2020). Lesy České republiky, s.p., Praha, 16 pp.

AnOnymus, 2019b: Cennik pre lov zveri v pol'ovnickej sezóne 2019/2020. Lesy Slovenskej republiky, š. p., Banská Bystrica, 20 pp.

ANONYMus, 2019c: Cenník pre lov zveri pol'ovnými hostami v pol'ovníckej sezóne. Platný od 1. marca 2019. Lesopol'nohospodársky majetok Ulič, š.p., Ulič, 8 pp.

Anonymus, 2019d: Katalóg z chovatel'skej prehliadky trofejí. Pol'ovnicka sezóna 2018/2019. Okresná pol’ovnícka komora, Humenné, 68 pp.

ANONYMus, 2020a: Katalóg z chovatel'skej prehliadky trofeji 2019/2020. Okresná pol'ovnícka komora, Humenné, 76 pp.

Anonymus, 2020b: Ceníky lovu 2019/2020 Divize Mimoň. Vojenské lesy a statky ČR, š.p., Mimoň, 2 pp.

Antal V., Boroš M., Čertíková M., Ciberej J., Dóczy J., FinĎo S., Kaštier P., Kropil R., Lukáč J., Molnár L., Paule L., Rigg R., Rybanič R. \& ŠrÁmka Š., 2016: Program starostlivosti o vlka dravého (Canis lupus) na Slovensku. Štátna ochrana prírody SR, Banská Bystrica, 115 pp.

Bleier N., Biró Z., Galló J., Szemethy L. \& Csányi S., 2013: Trend in game meat production and consumption in Hungary over the period 1970-2012. Pp.: 262-268. In: BeuKović M. (ed.): 2nd International Symposium on Hunting. Modern Aspects of Sustainable Management of Game. Proceedings. Faculty of Agriculture, University of Novi Sad, Novi Sad, [xii]+271 pp.

Bubelíny L'., 2014: Lov a jeho právna úprava. Dizertačná práca. Katedra práva životního prostředí, Právnická fakulta, Univerzita Karlova, Praha, 203 pp.

Bubnicki J. W., Churski M., Schmidt K., Diserens T. A. \& KuiJPer D. P., 2019: Linking spatial patterns of terrestrial herbivore community structure to trophic interactions. eLife, 8(e44937): 1-68.

Carpio A. J., Apollonio M. \& Acevedo P., 2020: Wild ungulate overabundance in Europe: contexts, causes, monitoring and management recommendations. Mammal Review, 51: 95-108.

Churski M., Spitzer R., Coissac E., Taberlet P., Lescinskaite J., Van Ginkel H. A. L., Kuijper D. P. J. \& Cromsigt J. P. G. M., 2021: How do forest management and wolf space-use affect diet composition of the wolf's main prey, the red deer versus a non-prey species, the European bison? Forest Ecology and Management, 479(118620): 1-21. 
Ciucci P., Mancinelli S., Boitani L., Gallo O. \& Grottoli L., 2019: Anthropogenic food subsidies hinder the ecological role of wolves: Insights for conservation of apex predators in human-modified landscapes. Global Ecology and Conservation, 21(e00841): 1-14.

Doenier P. B., DelGiudice G. D. \& Riggs M. R., 1997: Effects of winter supplemental feeding on browse consumption by white-tailed deer. Wildlife Society, 25: 235-243.

Felton A. M., Felton A., Cromsigt J. P., Edenius L., Malmsten J. \& Wam H. K., 2017: Interactions between ungulates, forests, and supplementary feeding: the role of nutritional balancing in determining outcomes. Mammal Research, 62: 1-7.

GARAJ P. ml. \& GARAJ P., 2007: Analýza obhospodarovania a trofejovej kvality jelenej zveri v účelovom pol'ovnom revíri Technickej univerzity vo Zvolene za ostatných 20 rokov. Acta Facultatis Forestalis Zvolen, 49: 53-65.

LeHOckÝ M. \& Kuric P., 2007: Podnikanie v pol'ovníctve a v chove pol'ovnej zveri. Národné lesnícke centrum, Zvolen, $70 \mathrm{pp}$

Hell P., Farkaš J., FinĎo S., Katreniak J., Kováč J., Opálený A., Sabadoš K. \& Siget F., 1983: Súčasný stav a perspektívy d’alšieho rozvoja pol'ovníctva na Slovensku. Pol’ovnícke Štúdie, 1983(8): 1-172.

Hell P., KonôpKa J., Sabadoš K., SlamečKa J., LehockÝ M., Farkaš J., GašParík J. \& SlameČKa J., 2004: Vel'koplošné ekologické obhospodarovanie zveri v rámci pol’ovných oblastí a lokalít. Pol'ovnícke Štúdie, 2004(10): 1-166.

Hell P., RAJSKÝ M. \& SlamečKa J., 2009: Je zmena metód CIC na hodnotenie trofejí zmysluplná? Myslivost, 2009(3): 18.

KašTier P., BuČKo J., KajBa M. \& CAPUliaK J., 2013: Štúdia rozvoja pol'ovníctva v okresoch Levice, Krupina, Vel'ký Krtíš, Detva a Lučenec. Národné lesnícke centrum, Zvolen, 75 pp.

Kropil R., Smolko P. \& Garaj P., 2015: Home range and migration patterns of male red deer Cervus elaphus in Western Carpathians. European Journal of Wildlife Research, 61: 63-72.

Möst L., Hothorn T., Müller J. \& Heurich M., 2015: Creating a landscape of management: Unintended effects on the variation of browsing pressure in a national park. Forest Ecology and Management, 338: 46-56.

PAule L. \& KrišTA J., 1984: Príspevok ku geografickej premenlivosti trofejí jeleňa obyčajného (Cervus elaphus L.). Folia Venatoria, 14: 29-42.

Perzanowski K. \& KrZakiewicz H., 2000: Populacja jelenia szlachetnego w Bieszczadach. Monografie Bieszczadzkie, 9: 157-178.

PČola Š. \& Adamec M., 2005: Program záchrany zubra hrivnatého (Bison bonasus Linnaeus, 1758). ŠOP SR, Banská Bystrica, 23 pp.

Rivrud I. M., Sonkoly K., Lehoczki R., Csányi S., Storvik G. O. \& Mysterud A., 2013: Hunter selection and long-term trend (1881-2008) of red deer trophy sizes in Hungary. Journal of Applied Ecology, 50: 168-180

Robb G. N., McDonald R. A., Chamberlain D. E. \& Bearhop S., 2008: Food for thought: supplementary feeding as a driver of ecological change in avian populations. Frontiers in Ecology and the Environment, 6: 476-484.

SCHERER P., 2014: Integrita systému medzinárodního hodnocení trofejí CIC silne ohrožená. Myslivost, 2014(4): 44.

Singer F. J. \& NoRland J. E., 1994: Niche relationships within a guild of ungulate species in Yellowstone National Park, Wyoming, following release from artificial controls. Canadian Journal of Zoology, 72: 1383-1394.

SLÁDEK J., 2011: Ochranárske aspekty vo filozofii pol'ovníctva na Slovensku v 20. storočí. Folia Venatoria, 40-41: 117-127.

Smolko P., Kropil R., Pataky T., Veselovikná A. \& Merrill E., 2018: Why do migrants move downhill? The effects of increasing predation and density on red deer altitudinal migration in temperate Carpathian forests. Mammal Research, 63: 297-305.

Šтоғíк J., 2019: Škody na pol'ovnej zveri - aký je správny postup a postavenie zástupcu ŠOP SR v tomto procese. Správa o šetreni škôd spôsobených velkými šelmami v rámci územnej pôsobnosti Správy NP Poloniny. ŠOP SR, Banská Bystrica, 5 pp. 
ŠTofík J., 2010: Upytliačený medved’ v Poloninách. Chránené Územia Slovenska, 80: 20-21.

Štofík J., Perinajová S. \& Perinaj M., 2019: Analýza úbytku (lovu a úhynu) raticovej zveri a legislatívnych aspektov ochrany prírody na hospodárske využitie pol’ovných revírov v Národnom parku Poloniny (východné Slovensko). Ochrana Prírody, 34: 21-36.

Urošević M., Urošević M., Drobnjak D., OĞrak Y. Z., Matarugić D. \& Petar S., 2017: Comparison of different systems of roe deer (C. capreolus) trophy evaluation. Turkish Journal of Agriculture - Food Science and Technology, 5: 207-213. 